\title{
KIRGIZ TÜRKÇESİNDE SES UYUMLARININ SEBEP OLDUĞU SES DEĞIŞMELERİ*
}

\begin{abstract}
Ahmet BURAN ${ }^{* *}$
Özet

Dillerde ünlü ve ünsüzlerde meydana gelen değişmelerin çeşitli sebepleri vardır. Bu değişimlerin bir bölümü, münasebette bulunulan diller, kültürler, iklim ve coğrafya gibi dilin "dış tarihi" ile ilgilidir. Diğer önemli bir kısmı ise, dilin iç dinamiklerinden kaynaklanan "dilin iç tarihi" ile ilgili değişme ve gelişmelerdir.

Türk dilinde ünlüler ile ilgili “kalınlık-incelik ve düzlük-yuvarlaklık”, ünsüzlerle ilgili de “tonluluk-tonsuzluk" uyumu adı verilen önemli ve özel bir uyum sistemi bulunmaktadır. Çağdaş Türk yazı dillerinde bu uyum sistemlerinin durumu önemli farklılıklar göstermektedir. Kırgız Türkçesi, çağdaş Türk yazı dilleri arasında ünlü ve ünsüz uyumlarını en ileri düzeye taşıyan ve en sağlam biçimde işleten yazı dilidir. Bu uyum sistemleri geliştikçe, dil kendi doğası gereği, kelime tabanlarında ve ekleşme durumunda karşılaştığı uyuma aykırı biçimleri değiştirip dönüştürerek uyuma uygun hale getirmektedir.

Türk yazı ve konuşma dillerinin tümünde bulunmakla birlikte, ünlü ve ünsüz uyumlarına bağlı ses değişmelerinin en karakteristik ve yaygın örnekleri, Kırgız Türkçesinde görülmektedir. Onun için bu çalışmada "ses uyumlarının sebep olduğu ses değişmeleri" Kırgız Türkçesi özelinde incelenmeye çalışılmıştır.

Ünlü uyumu, ünlülerin boğumlanma yeri (art-ön) bakımından benzerlik göstermesi ile ilgili bir uyumdur.

Türkiye Türkçesinde; "Kalınlık-incelik uyumu”, “damak uyumu”, “büyük ünlü иyитu” gibi terimlerle ifade edilen bu uyum için Kırgız Türkçesinde "tildin küüsü; kalın ündüü küüsü, ince ündüü küüsü” terimleri kullanılmaktadır.

Kalınlık-İncelik uyumu;Türkçe Kökenli Kelimelerde Kalınlık-İncelik Uyumu; Kalınlık Uyumu (kalın ündüü kü̈̈sü), İncelik Uyumu (İnce Ündü̈̈ Kü̈̈s̈̈; Yabanc1 Kökenli Kelimelerde Kalınlık-İncelik Uyumu başlıklarında ele alınmıştır. İnce Ünlülerin Kalınlaştırılması ve Kalın Ünlülerin İnceltilmesi Yoluyla Kalınlık-İncelik Uyumunun Sağlanması başlıkları ile de ünlü değişimleri örneklenerek nitelikleri gösterilmiştir.

Düzlük yuvarlaklık uyumu, çağdaş Türk yazı dillerinde farklı düzeylerdedir. Bu uyumun tanımı Türkiye Türkçesine göre değil Kırgız Türkçesine göre yapılmış ve değişim örnekleri bu tanım bağlamında incelenmiştir.

Düzlük-Yuvarlaklık Uyumunun Sebep Olduğu Ses Değişmeleri de Türkçe ve yabancı kelimelerde ayrı ayrı örneklenmiştir.

Çağdaş Türk yazı dillerinde yine farklı düzeylerde işletilen ünsüz uyumu (tonluluktonsuzluk), Kırgız Türkçesinde çok ileri düzeye taşınmıştır. Özellikle kelime kök ve tabanlarına getirilen eklerin uyum dolayısıyla değişime uğradıkları görülmektedir. Ünsüz uyumu dolayısıyla, özellikle tonsuz karşılığı olmayan, tonlu ünsüzlerle başlayan (Ör. 1Ar > lar, ler, lor, lör, dar, der, dor, dör, tar, ter, tor, tör) ekler, tonlu ve tonsuz ünsüzlerden biri ile biten kelimelere eklendiklerinde ünsüz uyumuna uyabilmek için değişirler.
\end{abstract}

\footnotetext{
* Bu makale, 22-26 Mayıs 2017'de Ankara'da Türk Dil Kurumu tarafından düzenlenen 8. Uluslararası Türk Dili Kurultayı'na sunulmuş bildirinin yeniden gözden geçirilmiş ve düzenlenmiş biçimidir.

** (Prof. Dr.) Frrat Üniversitesi, İnsani ve Sosyal Bilimler Fakültesi, Türk Dili ve Edebiyatı Bölümü, ELAZIĞ, Elmek: buran.ahmet@gmail.com
} 
Çalışmada, yukarıda belirtilen ünlü ve ünsüz uyumlarından kaynaklanan ses değişmeleri bir sistem dâhilinde örneklendirilerek incelenmiştir.

Anahtar Kelimeler: Uyum, Ses değişmeleri, Kalınlık-İncelik uyumu, DüzlükYuvarlaklık uyumu, Ünsüz uyumu.

\section{PHONETIC CHANGES CAUSED BY VOWEL HARMONY}

\section{Abstract}

There are various reasons for vowel and consonant changes in languages. Some of these changes are related to 'the external history' of a language such as contacted languages, climate and geography. The other reasons are related to 'internal history' of languages that caused by internal dynamics.

In Turkish, there is an important harmonical systems called 'palatal and labial harmony' in vowels; 'voiced-voiceless harmony' in consonants.

In modern Turkish dialects, the situation of this harmonical system presents different features. Among the other dialects, Kirghiz Turkish is the dialect that excels and runs perfectly the vowel and consonant harmony. The more this system expands language, naturally, changes the inconsistent forms that are encountered in words bases or stems as suffixes.

In all the written and spoken languages, the most common and characteristic examples related vowel and consonant are seen in Kirghiz Turkish. Hence, in this study the sound changes caused by sound harmony in Kirghiz Turkish will be examined.

Palatal harmony is about articulation spot (front-back) of vowels.

Palatal harmony that is also called as backness-frontness harmony in Turkey Turkish is termed as “tildin küüsü; kalın ündüü küüsü, ince ündüü küüsü” in Kirghiz Turkish.

Palatal Harmony is examined under the following titles: Palatal Harmony in Turkish Origin Words; Backness Harmony (kalın ündüü küüsü), Frontness Harmony (Ince Ündüü Kü̈̈sü); Palatal Harmony in Foreign Origin Words. Under the titles of Velarisation of Front Vovels and Palatalisation of Back Vowels, the vowels changes are illustrated and presented.

Labial harmony has different levels in modern Turkish written languages. In this study, the description of this harmony is accepted as in the Kirghiz Turksih not in Turkey Turkish and the examples are handled according to this description.

The examples of The Sound Changes Caused by Labial Harmony are illustrated individually as for the vowels and consonants.

In Kirghiz Turkish, the consonant harmony (voiced-voiceless harmony) that is operated in different levels in modern Turkish written languages is taken to further levels. Especially, the suffixes that are put on the root and the stem words tend to get into a phonetic change. Because of the consonant harmony, the suffixes which starts with a the voiced consonants that have no voiceless counterparts (for example 1Ar > lar, ler, lor, lör, dar, der, dor, dör, tar, ter, tor, tör) change when they come after a word that ends with eighter a voiced or voiceless consonants in order to ensure the harmony.

In this study, the sound changes that is caused by vowel and consonant harmony are examined by illustrated in a systematic method.

Key Words: Harmony, Sound change, Palatal harmony, Labial harmony, Consonant harmony. 
Sesler dilin temel birimleridir. İnsan dili, öncelikle sesten ibarettir ve ses ile vardır. İnsan diline ait sesler, "ünlüler" ve "ünsüzler" şeklinde iki temel gruba ayrılır.

Dil, anlama/bilme ve anlatma/bildirme/bildirişme ihtiyacından doğmuştur. İnsan doğası gereği, bu ihtiyacını, "en $a z$ çaba" harcayarak, en kısa sürede ve en kolay, en pratik biçimde gidermek ister. Dolayısıyla genel fonetikte olduğu gibi, Türk dilinin tarihi fonetiğinde de, tonsuz ünsüzlerden tonlulara, katı-patlamalı ünsüzlerden sızıcı ünsüzlere; tonlu, sızıcı ünsüzler ile, yarı ünlülerden de ünlülere doğru bir değişim eğilimi söz konusudur. Çünkü insan dilinde ünlüler, ünsüzlere göre daha kolay üretilen, daha kolay çıkarılan seslerdir.

Dillerde "en az çaba yasası" başta olmak üzere, ünlü ve ünsüzlerde meydana gelen değişmelerin çeşitli sebepleri vardır. Bu değişimlerin bir bölümü, münasebette bulunulan diller, kültürler, iklim ve coğrafya gibi dilin " $d \iota s ̧$ tarihi" ile ilgilidir. Diğer önemli bir kısmı ise, dilin iç dinamiklerinden kaynaklanan "dilin iç tarihi" ile ilgili değişme ve gelişmelerdir.

Türk dilinde ünlüler ile ilgili “kalınlık-incelik ve düzlük-yuvarlakllk”, ünsüzlerle ilgili de "tonluluk-tonsuzluk" uyumu adı verilen önemli ve özel uyum sistemleri bulunmaktadır. Bu sistemlerin ortaya çıkışı ve işleyişi de tamamen en az çaba yasası ile ilgilidir. Çünkü kalın ünlüler ağız boşluğunun arka/art kısmında, ince ünlüler ise ön kısmında boğumlanırlar. Bir kelimenin ilk hecesinde art/kalın bir ünlü varsa sonrakilerin de kalın, ön/ince bir ünlü varsa sonrakilerin de ince olması bir kolaylıktır. Aynı kolaylık ünsüzlerdeki tonluluk-tonsuzluk uyumu için de geçerlidir.

Çağdaş Türk yazı dillerinde bu uyum sistemlerinin durumu önemli farklılıklar göstermektedir. Özellikle, geç zamanda ve yapay yollarla yazı dili haline getirilmiş bazı çağdaş Türk yazı dillerinde ünlü ve ünsüz uyumları bozuktur. Bunun bir sebebi de dış etkilere maruz kalmış konuşma dillerinin yazı diline esas alınmış olmasıdır. Özbek Türkçesi bunun en başta gelen örneklerindendir.

Kırgız Türkçesi, Türk yazı dilleri arasında ünlü ve ünsüz uyumlarını en ileri düzeye taşıyan ve en sağlam biçimde işleten yazı dilidir. Bu uyum sistemleri geliştikçe, dil kendi doğası gereği, kelime tabanlarında ve ekleşme durumunda karşılaştı̆̆ uyuma aykırı biçimleri değiştirip dönüştürerek uyuma uygun hale getirmektedir. Bu durum sadece Türkçe kelimeler için değil, yabancı kökenli kelimeler için de geçerlidir.

Türk yazı ve konuşma dillerinin tümünde görülmekle birlikte, ünlü ve ünsüz uyumlarına bağlı ses değişmelerinin en karakteristik ve yaygın örnekleri, Kırgız Türkçesinde görülmektedir. Onun için, " ses uyumlarının sebep olduğu ses değişmelerini" Kırgız Türkçesi özelinde incelemeye çalıştık.

\section{Kalınlık-İncelik Uyumu (Kalın Ündü̈̈ Küüsü, İçke Ündüü Kü̈̈sü)}

Kalınlık-incelik uyumu, Altay dillerinin, dolayısıyla Türk dilinin karakteristik özelliklerinden biridir. Ünlülerin boğumlanma yeri (art-ön) bakımından benzerlik göstermesi ile ilgili bir uyumdur. Türkçede, kelimelerin ilk hecesindeki ünlünün niteliği ikinci hecenin ünlüsünün niteliğini belirlediği için, kalınlık-incelik uyumu ilk hece ünlüsü esas alınarak tanımlanır. Ancak, ilk hece ünlüsü ikinci heceyi belirledikten sonra devre dışı kalır ve kural bir önceki hecenin ünlüsünün niteliğinin bir sonraki hecenin ünlüsünün niteliğini belirlemesi şeklinde devam eder. Bu bilgiler ışığında, kalınlık-incelik uyumunu şöyle tanımlayabiliriz: Kalınlık-incelik uyumu, bir kelimenin ilk hecesinde kalın bir ünlü varsa sonraki hecelerde yer alan ünlülerin de kalın, bir kelimenin ilk hecesinde ince bir ünlü varsa sonraki hecelerde yer alan ünlülerin de ince olması kuralıdır. Esasen bu uyumlardan kalınlık uyumu ayrı incelik uyumu ayrı uyumlardır. İki uyum arasında sadece bir karşıtlık iliş̧isi vardır. 
Türkiye Türkçesinde; "Kalınlık-incelik uyumu”, “damak uyumu”, "büyük ünlü иyumu” gibi terimlerle ifade edilen bu uyum için Kırgız Türkçesinde "tildin kü̈̈sü; kalın ündü̈ küüsü, içke ündüü küüsü” terimleri kullanılmaktadır.

Kalınlık-incelik uyumu iki ayrı uyumdan oluştuğu için biz konuyu "Kalınlık Uyumu” ve “İcelik Uyumu” başlıklarıyla ayrı ayrı ele alacağız.

\subsection{Kalınlık Uyumu (Kalın Ündü̈̈ Kü̈̈sü)}

\subsubsection{Türkçe Kökenli kelimelerde}

Kırgız Türkçesinde kullanılan Türkçe kökenli kelimelerde kalınlık uyumu sağlam bir şekilde işlemektedir: okuuçumun, kıskarak cakşılık, turgan, balalı, uulu, cıluu, aldooçu, koldongondo, açkıç, coldoş, tışkarı,

Türkiye Türkçesinde uyuma girmeyen; alma (elma), kana (<ET. kanı>hani), karındaş (kardeş), kaysı, gibi kelimeler, Kırgız Türkçesinde eski şekillerini korur ve kalınlık uyumuna uyarlar.

\subsubsection{Yabancı Kökenli Kelimelerde}

Kalınlık uyumu Kırgız Türkçesinde kullanılan yabancı kökenli kelimeleri de etkilemektedir. Dolayısıyla, kaynak dildeki özgün biçimleri kalınlık uyumuna uymayan çok sayida kelimenin uyuma sokulduğu görülmektedir: adat ( $<$ Ar. âdet), alaamat ( $<$ Ar. 'alâmet), daavat ( $<$ Ar. da'vet), kubat ( $<$ Ar. kuvvet), makala $(<$ Ar. makâle), daana $(<$ Far. dâne), azan $(<$ Ar. ezân), balaa ( $<$ Ar. bela'), camal $(<$ Ar. cemal), mazar $(<$ Ar. mezâr), tamaşa $(<$ Far. temâşâ), almas ( $<$ Ar. elmâs), camal $(<$ Ar. cemâl)

\subsubsection{Kalınlık Uyumuna Aykırı şekiller}

\subsubsection{Türkçe Kökenli Kelimelerde}

+ek, +yek, +ke, +eke, +key, +ge ve +ker ekleri kalın ünlülü kelimelere geldiğinde uyuma aykırı düşerler: koyonek (tavşan yavrusu), kırgıyek (genç atmaca), apake, atake, bayke, tayeke, kılıçker, kırgıyek, balakey, bayge, kantip.

\subsubsection{Yabancı Kökenli kelimelerde}

Bazı yabancı kökenli kelimelerdeki ünlüler özgün şekillerini korur ve uyuma aykırı düşerler: kollektiv, pabrika, partiya, mamile, naçalnik, aktiv, komandir, zalök vb.

dalil (<Ar. delil), postek (<Far. pösteki) gibi bazı örneklerde ise kelimelerin özgün şekilleri değiştirildiği için uyuma aykırılık oluşmuştur.

Ayrıca, + ker ve + ke ekleri ile kullanılan kalın ünlülü kelimelerde kalınlık uyumu bozulur: talapker, carooker (şefkatli) carmanke (Rus. yarmarka)

\subsubsection{Kalınlık Uyumunun Sebep Olduğu Ses Değişmeleri}

\subsubsection{1.İnce Ünlülerin Kalınlaşması}

Kırgız Türkçesinde yer alan yabancı kökenli kelimelerin bir bölümü, kaynak dildeki özgün biçimleri bakımından kalınlık uyumuna aykırı sesler bulundururlar. Kırgız Türkçesi, bu kelimelerin çok önemli bir bölümünde yer alan bu aykırı sesleri 
uyuma zorlar ve değiştirir. Uyuma girme yönünde meydana gelen ünlü değişmelerinin büyük bir kısmında ince ünlülerin kalınlaştığı görülür. Değişimler, değişmenin yönüne göre ilerleyici veya gerileyici benzeşme yoluyla gerçekleşir.

e>a değişmesi:

İlerleyici Benzeşme Yoluyla: adat ( $<$ Ar. âdet), alaamat ( $<$ Ar. 'alâmet), daavat $(<$ Ar. da'vet), esep ( $<$ Ar. hesâb), kubat $(<$ Ar. kuvvet), makala ( $<$ Ar. makâle), daana ( $<$ Far. dâne)

Gerileyici benzeşme Yoluyla: azan ( $<$ Ar. ezân), balaa ( $<$ Ar. bela'), mazar ( $<$ Ar. mezâr), tamaşa ( $<$ Far. temâşâ), almas ( $<$ Ar. elmâs), camal $(<$ Ar. cemâl)

İlerleyici ve gerileyici Benzeşme Yoluyla: zıyarat ( $<$ Ar. ziyâret), akıkat ( $<$ Ar. hakikat), amanat $(<$ Ar. emânet), zlyapat $(<$ Far. Ziyâfet), taza $(<$ Far. tâze)

\section{i>1 değişmesi:}

İlerleyici benzeşme Yoluyla: adıl ( $<$ Ar. $>$ adl $>$ âdil), zayır ( $<$ Ar. zahir), akır ( $<$ Ar. âhir)

Gerileyici benzeşme Yoluyla: 1ktıbar ( $<$ Ar. i’tibâr), 1ktımal ( $<$ Ar. ihtimâl), 1ktıyar ( $<$ Ar. ihtiyâr), 1lac ( $<$ Ar. ilâc), 1mân ( $<$ Ar. imân), ınsan ( $<$ Ar. insân), mıras ( $<$ Ar. miras), nıyaz $(<$ Far. niyâz), zına ( $<$ Ar. zinâ), zıyan ( $<$ Far. ziyân)

İlerleyici ve Gerileyici benzeșme Yoluyla: barat ( $<$ Ar. ibâret), ziyarat ( $<$ Ar. ziyâret), 1şaarat $(<$ Ar. işâret $)$

i $>$ a değişmesi: taraba $(<A r$. terâvîh $)$

\section{2. İncelik Uyumu (İçke Ündü̈̈̈ Küüsü)}

\subsubsection{Türkçe Kökenli Kelimelerde}

Kırgız Türkçesinde kullanılan Türkçe kökenli kelimelerde incelik uyumu sağlam bir şekilde işlemektedir: cigitter, süylöbödü, bergenbiz, cergiliktüü, iygilik, köyüldüü, cöö, cüröksüz, ketişiptir, körsönör, kezgin

Türkiye Türkçesinde uyum dışı kalan anne, dilmaç gibi bazı kelimeler Kırgız Türkçesinde ene (anne), tilmeç (dilmaç) biçiminde kullanılır ve incelik uyumuna uyarlar.

\subsubsection{Yabancı Kökenli Kelimelerde}

Kırgız Türkçesinde doğal bir kural halinde ve yaygın bir biçimde işleyen incelik uyumu, yabancı kökenli kelimelerde de etkili olmakta ve onları da büyük oranda uyuma sokmaktadır. Yabancı kökenli kelimelerin ön, iç ve son seslerinde yer alan uyuma aykırı sesler, uyum açısından daha güçlü olan sesler tarafından kendine benzeştirilerek uyuma uygun hale getirilir Ör. kümön (<Far. gümân), dükön (<Ar. dükkân); süröt (<Ar. suret)

\subsection{3.İncelik Uyumuna Aykırı Şekiller}

\subsubsection{Türkçe Kökenli Kelimelerde}

+tAy eki ince sıradan ünlülerle başlayan kelimelere getirildiğinde uyum dışı kalır: eketay (babacık), initay (kardeşçik), cenetay (yengeciğim), kementay (keçeden yapılan üst giyim) 


\subsubsection{Yabancı Kökenli Kelimelerde}

Yabancı kökenli kelimelerin bir bölümü incelik uyumuna uydurulmadan kullanılır: işkana, kitepkana, ideal, filosof, militsiya, seriya, sentyabr, sekretar, icara, dialekt vb.

\subsection{4. İncelik Uyumunun Sebep Olduğu Ses Değişmeleri}

\subsubsection{Kalın Ünlülerin İncelmesi}

â $>\mathbf{e}$ değişmesi: kiteb (Ar. $<$ kitâb), adam(Ar. $<$ âdem), esep ( $<$ Ar. hesâb),

â>ö değişmesi: kümön (<Far. gümân), dükön ( $<$ Ar. dükkân), möösül (Ar. muhâsil)

u>ü değişmesi: süröt (<Ar. suret), şügür (<Ar. şukr), kümböz (<Far. gunbed), kübö $(<$ Far. guvâh)

u >ö değişmesi: möösül (Ar. muhâsil), öküm (<Ar. hukm)

\section{Düzlük-Yuvarlaklık Uyumu (Erin Küüsü)}

Düzlük-yuvarlaklık uyumu (dudak uyumu) çağdaş Türk lehçelerinde önemli farklılıklar gösterir. Bu farklılık dolayısıyla düzlük-yuvarlaklık uyumunun tanımı da farklıdır. Türkiye Türkçesinde düzlük yuvarlaklık uyumu; bir kelimenin ilk hecesinde düz bir ünlü (a.e.1.i) varsa sonraki hecelerde yer alan ünlülerin de düz, yuvarlak bir ünlü $(o, \ddot{o}, \mathrm{u}, \ddot{u})$ varsa, sonraki hecelerde yer alan ünlülerin ya dar-yuvarlak (u, ü) ya da genişdüz $(\mathrm{a}, \mathrm{e})$ olması kuralıdır, şeklinde tanımlanır. Esasen düz ünlülerin uyumunda bir farklılık yoktur. Farklılık, yuvarlaklık uyumunda ortaya çıkmaktadır.

Kırgız Türkçesinde, kök hecede yuvarlak yahut yuvarlaklaşmış bir ünlü bulunduran kelimelerin sonraki hecelerinde yer alan ünlüler dudak uyumuna uymak için yuvarlaklaşırlar. Dolayısıyla Kırgız Türkçesinde düzlük-yuvarlaklık uyumunu; bir kelimenin ilk hecesinde düz bir ünlü varsa sonraki hecelerde yer alan ünlülerin de düz, yuvarlak bir ünlü varsa sonraki hecelerde yer alan ünlülerin de yuvarlak olmas1 kuralıdır, şeklinde tanımlayabiliriz. Bu kuralın en belirgin istisnası, birinci veya sonraki hecelerde bulunan dar-yuvarlak u ünlüsünden sonra düz-geniş a ünlüsünün gelebilmesidir. Ayrıca az sayıda örnekte, ilk seste ikincil bir uzun o (oo) oluşmuşsa bu o sesinden sonra da a ünlüsü gelebilmektedir. Ooba (<evet), oopa (<vefa), oodar(<aktar-), oona-, (<ă̆na-),oozan (<ă̆ızan-)

Düzlük-yuvarlaklık uyumu terimiyle ifade edilen ses uyumu da esasen iki ayrı uyum sistemini içerir. Bunlardan biri, düzlük uyumu, diğeri yuvarlaklık uyumudur. Bu iki uyum arasındaki ilişki de düzlük ve yuvarlaklık bakımından bir karşıtlık ilişkisidir. Biz, kalınlık иуити ve incelik иуити gibi düzlük ve yuvarlaklık uyumlarını da ayrı başlıklar halinde incelemeye çalışacağız.

\subsection{Düzlük Uyumu}

\subsubsection{Türkçe Kökenli Kelimelerde}

Kırgız Türkçesinde kullanılan Türkçe kökenli kelimelerde, düzlük uyumu sağlam bir kural halinde işlemektedir: iygilik, cerdeşibiz, cabık, bargan, keldi, bışkan, tınçtık, elder, bizdin, baldarıbız, baarınar, camgır, kamır, ketiptirsin, çıgarmanı 
Türkiye Türkçesinde düzlük uyumuna uymayan yağmur, hamur gibi bazı kelimeler Kırgız Türkçesinde camgır, kamır biçiminde uyuma uygun şekilde kullanılırlar.

\subsubsection{Yabancı Kökenli kelimelerde}

Düzlük uyumuna uymayan yabancı kökenli kelimeler de ses değişmelerine uğrayarak düzlük uyumuna uygun hale gelirler. taraza $(<A r$. terâzû), samın $(<A r$. sâbûn), makmal $(<A r$. muhmal, şeker $(<A r$. şukkar), sünnöt $(<$ Ar. sunnet), moldo $(<$ Ar. mulla), maarek $(<$ mubârek)

\subsubsection{Düzlük Uyumuna aykırı şekiller}

\subsubsection{Türkçe Kökenli Kelimelerde}

Türkçe kökenli kelimelerde özellikle düz ünlü ile başlayan fiillerin mastar biçimleri, -Ig ekinin sonundaki g sesinin önce v'leşmesi ardından da yuvarlak ünlüye dönüşmesi sebebiyle uyuma aykırı düşerler. (-Ig> Iv>uu /oo) almaştıruu (karıştırmak, değiştirmek), aydoo (sürmek), kıştoo (kışlamak), baştoo (başlamak), çıguu (çıkmak/çıkış), kirüü (girmek/girişs), karoo (bakmak), clynoo (toplamak), izdöö (aramak), tırmoo (tırmıklamak)

Aynı durum +lIg ekinde de (lıg>lıv>luu) görülür. Düz ünlü ile başlayan kelimelere bu ek getirildiğinde düzlük uyumu bozulmaktadır: eerdü̈̈ (ĕgerli), ataktuu (ünlü)

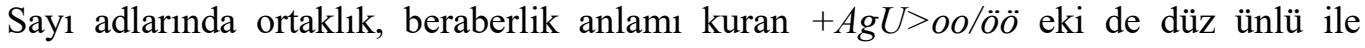
başlayan kelimelere geldiğinde uyumu bozar: biröö (her biri), eköö, üçöö

-çU eki de kimi örneklerde düz ünlülü tabanlara yuvarlak ünlülü biçimde gelerek uyumu bozar: es alçu, berçü söz

\subsubsection{Yabancı Kökenli kelimelerde}

Yabancı kökenli, akılduu (akıll), paydaluu (faydall), daamduu (lezzetli), şekildü̈ (şekilli) gibi kelimelere de luu (<+lıg) eki getirildiğinde düzlük uyumu bozulmaktadır.

Kırgız Türkçesinde özgün biçimlerini koruyan bazı yabancı kökenli kelimeler düzlük uyumuna uymazlar: avtor (yazar), kuda (dünür), rayon

\subsubsection{Düzlük Uyumunun Sebep olduğu Ses Değişmeleri \\ 2.1.4.1. Yuvarlak Ünlülerin Düzleşmesi}

\subsubsection{1.a.Türkçe Kökenli kelimelerde}

u>> değişmesi: bırış- (<buruş-),

ü>i değişmesi: eçki (<eçkü)

\subsubsection{1.b.Yabancı Kökenli Kelimelerde}

u>a değişmesi: maalım ( $<$ Far. malûm), tabıt $(<$ Ar. tâbût)

u>> değişmesi: kabıl (Ar.<kabul), namıs (Ar.<namus), malım (Ar.<malûm) 


\subsection{Yuvarlaklık Uyumu}

\subsubsection{Türkçe Kökenli Kelimelerde}

Kırgız Türkçesinde kullanılan Türkçe kökenli kelimelerin önemli bir bölümünde yuvarlaklık uyumu vardır: ötösünör, konoktor, coldoş, köçmön, küçtüü, kotormoçu, burun, moyun, köpölökördön, tuuldu, töbö, koldonuu, coldoş

\subsubsection{Yabancı Kökenli kelimelerde}

Özgün biçimleri yuvarlaklık uyumuna aykırı olan bazı yabancı kelimeler uyuma uygun hale getirilerek kullanılır: köçö (<köşe), böödö(<beyhûde), orozo (<rûze), ücürö $(<A r$. hucre), düynö ( $<A r$. dünyâ), toos ( $<A r$. tâvus), şoorat $(<A r$. şuhret), müşkül $(<$ Ar. muşkil)

\subsubsection{Yuvarlaklık Uyumuna Aykırı şekiller}

\subsubsection{Türkçe Kökenli kelimelerde}

Kırgız Türkçesinde az da olsa yuvarlak o ve u ünlülerinden sonra a ünlüsü gelebilmektedir. Bu durum, yuvarlaklık uyumunun nihaî şekli olan 'yuvarlak ünlülerden sonra yuvarlak ünlülerin gelmesi' kuralının eksik kalan yanı olarak değerlendirilebilir: uçuraşkanı (selamlaşmak için), bolmoyunça, körmöyünçe, tuuganbı, murda(önce)

\subsubsection{Yabancı Kökenli kelimelerde}

Bazı yabancı kökenli kelimeler yuvarlaklık uyumuna uydurulmadan kullanılır: opera, profesör, obyekt, obyektiv, oklya

\subsubsection{Yuvarlaklık Uyumunun Sebep Olduğu Ses Değişmeleri}

\subsubsection{Düz Ünlülerin Yuvarlaklaşması}

\subsubsection{1.a. Türkçe Kökenli Kelimelerde}

\section{a>o değişmesi:}

İlk hecedeki o ünlüsünden sonra gelen a'lar, yuvarlaklık uyumuna uyabilmek için o'ya dönüşürler. Örneklerden de anlaşıldığı gibi ilk hecedeki o sesi genellikle aslidir. Kimi zaman ilk, kimi zaman da diğer hecelerdeki o ünlüsü, yuvarlaklık uyumu dolayısıyla ikincil bir ses olarak oluşmuştur. Ancak uyum dolayısıyla ortaya çıkan bu ikincil şekiller, Kırgız Türkçesinde kalıcı hale gelmişlerdir. böbök (<bebek), döbö (<tepe)

İlerleyici benzeşme Yoluyla: boşot-, boyo, bozo, bozor-, cokto-, coldo-, coldoş, koldon-, konok, korkok, ormon, orok, orto, ortok, oynogon, tokmok, toptop (<toplayıp)

\section{e>ö değişmesi:}

İlk hecedeki ö veya ü ünlülerinden sonra gelen e'ler, yuvarlaklık uyumuna uyabilmek için ö'ye dönüşürler. $\mathrm{Bu}$ yuvarlaklaşmaların bir bölümü dudak ünsüzlerinin etkisiyle oluşmaktadır: üy (<ew<eb), süy- (<sew-<seb-), üyür- (<ewir<ebir-), bölmö, köpölök, döbö vb. 
İlerleyici Benzeşme Yoluyla: böbök, böcök, bölmö, cönöl-, döbö, köçmön, kömök, köpölök, köynök, ölkö, özgö, süylö-, sürmö, üyröt, cürök,

l>u değişmesi: aruu (aruv < arıg), ayuu (<aduv $<$ adıg)

i>ü değişmesi: elüü $(<$ elüv< <lig)

\subsubsection{1.b. Yabancı Kökenli Kelimelerde}

a>o değişmesi: şooruk ( $<$ Ar. şahruh) kulfat)

a< ö değişmesi: kümön (<Far. gümân), möösül (Ar. muhâsil), külpöt (Ar.

e>o değişmesi: moolut ( $<$ Ar. mevlüt),

e>ö değişmesi: böödö (<Far. beyhude< bîhûde), kööne (<Far. Köhne), süröt (<Ar. suret)

i>ü değişmesi: möösül (Ar. muhâsil),

\section{3. Ünsüz Uyumu}

Tonluluk-tonsuzluk, süreklilik-süreksizlik gibi terimlerle ifade edilen bu uyumun Türk dilinin tarihî ve çağdaş lehçelerinde farklı düzeylerde yaşatıldığı ya da yansıtıldığ bilinmektedir.

Çağdaş Türk lehçeleri arasında ünsüz uyumunu en ileri düzeyde işleten yazı dili Kırgız Türkçesidir. Kırgız Türkçesinde, tonlu bir ünsüzle biten kelimeye getirilen ek tonlu, tonsuz bir ünsüzle bitten kelimeye getirilen ek de tonsuz bir ünsüzle başlar. Bilindiği gibi Türkçede, $b-p, c$ $c, d-t, g-k$ gibi seslerin tonlu ve tonsuz karşıllkları varken $f, s, s, h$ gibi tonsuz ünsüzlerin tonlu ve $j, l, m, n, r, v, y, z$ gibi tonlu ünsüzlerin de tonsuz karşılıkları yoktur. Dolayısıyla kelime kök ya da tabanlarına tonlu ya da tonsuz ünsüzlerden biri ile başlayan bir ek getirildiğinde bu ek ya uyum dışı kalır ya da ekin ilk sesi değişikliğe uğrayıp kelime tabanının son sesine uyar ve ünsüz uyumuna uygun hale gelir.

Kırgız Türkçesinde yukarıda belirtilen durumdaki ekler ses değişmesine uğrayarak ünsüz uyumuna uygun hale gelmektedir. Tarihî metinleri olmadığı için Kırgız Türkçesindeki bu değişme ve gelişmenin tarihî sürecini tespit etmek mümkün olmasa da, Türkçenin ilk yazılı belgelerindeki biçimleri esas alarak değişmin yönünü tespit etmek mümkündür.

\subsection{Tonluluk Uyumu}

Tonsuz karşıllı̆ı olmayan tonlu ünsüzlerden biriyle $(\mathrm{m}, 1, \mathrm{n})$ başlayan bazı ekler tonsuz karşıllı̆ 1 olan tonlu ünsüzlerden birine $(\mathrm{m}>\mathrm{b}, \mathrm{l}>\mathrm{d}, \mathrm{n}>\mathrm{d})$ dönüşerek ekin her durumda uyuma girmesini sağlarlar. Aşağıda bu değişime uğrayarak tonluluk uyumuna giren örnekler yer almaktadır:

\subsection{1. $m>b$ değişmesi:}

-mA olumsuzluk ekinde: alba-, körbö-, ötünbö-,bolbo-

-mAs ekinde: albas-, körbös-, berbes-, bolbos-

-mA(y) ekinde: okubay catasın, kelbey cürösün, körböy kaldık

mI soru ekinde: bilesinbi, süylögön üçünbü, oşondoybu 


\subsubsection{I $>$ d değișmesi:}

+lAr ekinde: elder, güldör, klzdar, coldor, ketkender

+lA- ekinde: ündö-, koldo-, klzılda-, tegizde-, közdö-

+lIk ekinde: ösümdük, tuugandık, körkömdük, koyluk, koomduk

+IUU(<IIg>lı) ekinde: köyüldüü, daamduu, akılduu

+lAş- ekinde: salamdaş-, cüzdöşs, kollektivdeş-

+lAn- ekinde: candan-, irden-, kuraldan-

\subsection{3. $n>d$ değişmesi:}

+nI ekinde: sözdördü, ayıldl, dindi, ögüzdü

+nIn ekinde: tündün, üydün, bizdin, adamdın, könüldün, tördün

\subsection{Tonsuzluk Uyumu}

Tonlu ve tonsuz karş1lkları olan ünsüzlerle başlayan ekler her halükârda kelime tabanındaki ünsüzün niteliğine uydukları için ünsüz uyumuna uyarlar. Tonsuz karşılıkları bulunmayan ünsüzler $(1, \mathrm{~m}, \mathrm{n})$ ile başlayan eklerin ilk sesi kelime tabanının son sesinin niteliğine göre bir değişmeye uğrayarak $(1>t, m>p, n>t)$ uyuma uygun hale gelir. Alıntı kelimelerde kelime kökünde de bu durum görülebilir: tekpir ( $<$ Ar. tekbîr), tespe ( $<$ Ar. tesbîh).

Aşağıda verilen örneklerde tonlu ünsüzler tonsuzlaşmış ve böylece ekleşme sırasında tonsuzluk uyumu sağlanmıştır.

\subsubsection{Tonlu Ünsüzlerin Tonsuzlașması}

\subsubsection{I>t değișmesi:}

+lAr ekinde: böböktör, cigitter, ayaktar, coldoştor, kitepter

+lı (<IIg) ekinde: küçtüü, ataktuu, eseptüü,

+lIk ekinde: tınçtık, caştık, töştük, baştık

+laş- ekinde: betteş-, dostoş-, çataktaş-, togoloktoş-

+lan- ekinde: örttön-, kllıktan-, koopton-

+la- ekinde: klşsta-, tişste-, taşta-, otto-, kllıçta-

\subsubsection{2. $m>p$ değişmesi:}

-mA Olumsuzluk ekinde: korkpo-, uruşpa-, açpa-, küröşpö-

mI Soru Ekinde: albaspl, tolukpu

\subsubsection{3. $\quad b>p$ değişmesi:}

bız (<biz>vüz>Iz) ekinde: caşpız, studentpiz, oruspuz, cölökpüz (yardımcıyız) 


\subsubsection{4. $n>t$ değişmesi:}

+nI ekinde: cooptu, cüröktü, taştl, kılıçtl, tamaktı

+nIn ekinde: soğuştun, Nemetstin, cigittin

\section{3. Ünsüz uyumuna Aykırı Şekiller}

Kırgız Türkçesinde diğer ekler tonlu ve tonsuz karşılıklarıyla kullanıldığı için genellikle ünsüz uyumuna uyarken, $+c ̧ A,+c ̧ I,+c ̧ A k,+c ̧ A n+,+c ̧ U k,+c ̧ A,+c ̧ U$, çO gibi ç ünsüzü ile başlayan ekler tek şekilli olarak kullanılır ve uyum dışı kalırlar: cançık, caşılç̧a, çapançan, emçek, Kırgızça, kiyimçan, muzooçan, okuuçu, oyçu, oyunçuk, taarınçak, ekinçi, üçünçü, bölçök, alçu, cüzçö, oronçook.

$+k A,+k A y,+D A y,+k U,-m A k$ ve bazı fiillerde -Dır- ekleri de ünsüz uyumuna aykırı düşerler. biltırkl, bügünkü, murunku, sonku, öltür-, keltir-, kaltır-, çakmak, çertmek, altoo

\section{Sonuç}

Türk dilinde ünlü ve ünsüz uyumlarının sebep olduğu ses değişmeleri vardır. Bu ses değişmelerinin en düzenli ve en ileri düzeydeki örnekleri Kırgız Türkçesinde görülmektedir.

Kırgız Türkçesinde, ünlü uyumlarından kaynaklanan ünlü değişmelerinde, değişimin yönü ünlü kalınlaşması ve ünlü yuvarlaklaşması yönündedir. Özellikle ünlü yuvarlaklaşması eğilimi Kırgız Türkçesinde "yuvarlaklık uyumu"nu kendine özgü bir hale getirmiş ve oldukça ileri bir düzeye taşımıştır. Bu bağlamda uyuma aykırı yabancı kökenli kelimeler de uyuma uydurulmuştur. Uyumlara aykırı yapıların örnekleri azdır.

Ünsüz uyumlarından kaynaklanan ses değişmeleri, daha çok tonsuz karşıllı̆̆ olmayan seslerle başlayan eklerde (1, m, n) görülmektedir. Eklerin ilk sesleri, kelime köklerinin son seslerine göre tonlu ya da tonsuz (d-t, b-p) biçim alıp ünsüz uyumuna uygun hale gelirler. Ekleşmeye bağlı olarak ortaya çıkan bu değişme eğilimi genişleyerek yabancı kökenli kelimeleri de etkilemiştir. Ünsüz uyumuna aykırı düşen örnekler oldukça sınırlıdır.

\section{Kaynakça}

BAŞDAŞ, C.-KUTLU, A. (2004). Kırgız Türkçesi Grameri. Diyarbakır.

BİYAliYEV, A., (2002). Kırgız Adabiy Tili Cana Anın Adabiy Norması. Bişkek.

BURAN,A.-ALKAYA E., (2014). Çağdaş Türk Yazı Dilleri-3. Ankara: Akçağ Yay.

CUMAKUNOVA, G., (2008). Kırgız Türkçesinde Arapçadan Alıntı Kelimeler. Hacettepe Üniversitesi Türkiyat Araşttrmalart. Y. 5, S. 9, Güz, s. 101-117.

ÇENGEL, H.K., (2005). Kırgız Türkçesi Grameri. Ankara: Akçağ Yay.

DAVLATOV. C- KUDAYBERGENOV C., (1980). Azırkı Kırgız Tili. Frunze

DOĞAN, Levent vd. (2007). Çăgdaş Türk Lehçeleri El Kitabı. İstanbul: Kriter Yay.

GÜLENSOY, T., (2004). Kırgız Türkçesi Grameri. Kayseri.

NASKALİ, E. G., (1997). Türk Dünyası Gramer Terimleri Kılavuzu. Ankara: TDK Yay.

ÖNER, M., (1998). Bugünkü Klpçak Türkçesi. Ankara: TDK Yay.

TINISTAN UULU, K., (1998). Ene Tilibiz 1-2. İstanbul. 